\title{
Perbandingan Pengaruh Profitabilitas Leverage dan Pertumbuhan Perusahaan Terhadap Nilai Perusahaan
}

(Sub-Sektor Pertambangan Baru Bara dan Sub Sektor Pertambangan Minyak Mentah dan Gas Alam)

\author{
Nadiyasari $^{1}$, Rilla Gantino ${ }^{2}$ \\ ${ }^{1}$ Program Studi Akuntansi Universitas Esa Unggul \\ ${ }^{2}$ Dosen FEB Akuntansi Universitas Esa Unggul \\ 1nadiyasari28@gmail.com \\ 2rilla.gantino@esaunggul.ac.id
}

\begin{abstract}
Abstrak
Penelitian ini bertujuan untuk menganalisis tentang pengaruh profitabilitas, leverage dan pertumbuhan perusahaan terhadap nilai perusahaan. Profitabilitas diukur dengan ROA, Leverage diukur menggunakan DER dan pertumbuhan perusahaan diukur menggunakan sales growth. Metode statistik yang digunakan adalah analisis regresi linier berganda. Populasi dalam penelitian ini adalah perusahaan sub sektor pertambangan batu bara dan sub sektor pertambangan minyak mentah dan gas alam yang terdaftar di Bursa Efek Indonesia periode 2015 - 2019 terdiri dari 31 sampel dengan menggunakan teknik sampling jenuh. Hasil penelitian ini menunjukkan bahwa profitabilitas, leverage dan pertumbuhan perusahaan secara simultan berpengaruh signifikan terhadap nilai perusahaan pada sub sektor pertambangan batu bara. Sedangkan pada perusahaan sub sektor pertambangan minyak mentah dan gas alam bahwa profitabilitas, leverage dan pertumbuhan perusahaan secara simultan tidak berpengaruh signifikan terhadap nilai perusahaan.
\end{abstract}

Kata Kunci : Profitabilitas, Leverage, Pertumbuhan Perusahaan, dan Nilai Perusahaan.

\section{Pendahuluan}

Perusahaan dituntut untuk bisa melakukan persaingan di pasar domestik dan internasional agar dapat mempertahankan dan juga mendapatkan profit dengan memberikan perhatian secara maksimal kepada tindakan operasional dan finansial perusahaan. Tindakan ini berhubungan dengan upaya yang dilakukan perusahaan untuk bisa mencapai tujuannya, seperti tujuan yang mempunyai sifat jangka panjang maupun tujuan yang bersifat jangka pendek. Tujuan yang bersifat jangka pendek yakni seperti memperbanyak pendapatan usaha dengan menggunakan sumber daya yang dimiliki dan tujuan jangka panjang yaitu bisa memberikan peningkatan terhadap nilai suatu perusahaan serta bisa memberikan kesejahteraan pada pihak investor. Pada dasarnya nilai perusahaan bisa dilakukan pengukuran dengan menggunakan berbagai aspek, diantaranya menggunakan harga saham perusahaan pada pasar modal. Hal ini mempunyai hubungan yang positif dengan nilai perusahaan (Suwardika \& Mustanda, 2017)[1]

Terdapat berbagai faktor yang dapat memberikan pengaruh terhadap nilai suatu perusahaan dan pada penelitian ini diambil profitabilitas, leverage dan pertumbuhan 
perusahaan. Profitabilitas merupakan rasio yang menunjukan apabila nilai ROA semakin tinggi maka hal ini akan membuat kenaikan terhadap tingkat efisiensi dalam pemakaian aset perusahaan untuk mendapatkan laba yang bersih dan laba yang lebih besar, oleh karena itu perusahaan akan melakukan penilaian terhadap tingkat profitabilitasnya, pengukuran profitabilitas diukur dengan memakai Return On Asset (ROA). Ukuran pendapatan suatu perusahaan bisa memberikan pengaruh yang positif bagi nilai suatu perusahaan itu sendiri dimana ketika rasio ROA mengalami kenaikan maka akan diikuti pula dengan kenaikan nilai perusahaannya. Jika nilai ROA semakin tinggi maka hal ini akan membuat nilai perusahaan akan menjadi tinggi (Ecodemica et al.,2019)[2]. Selanjutnya variabel leverage merupakan variabel yang dibuat untuk bisa mengetahui sejauh mana aset yang ada pada perusahaan yang dilakukan pembiayaan dengan hutang apabila dibandingkan dengan pembiayaan yang dilakukan menggunakan modal pribadi. Leverage bisa dilakukan pengukuran dengan memakai Debt to Equity Ratio (DER). Jika leverage yang diproksikan dengan DER mengalami peningkatan maka hal ini akan mengakibatkan terjadinya peningkatan terhadap nilai perusahaan atau sebaliknya. Fenomena ini memperlihatkan jika DER memiliki pengaruh yang baik bagi suatu perusahaan. Sedangkan pertumbuhan pada perusahaan adalah rasio pertumbuhan yang memberikan gambaran terhadap kompetensi perusahaan untuk menjaga posisi ekonomi yang ada pada perusahaannya di tengah perkembangan perekonomian serta sektor usaha (Wahyudi, 2016)[3]. Pertumbuhan penjualan dapat digunakan untuk melakukan pengukuran terhadap besarnya pertumbuhan yang ada pada suatu perusahaan (Sales Growth). Apabila rasio perkembangannya semakin tinggi maka hal ini membuat nilai perusahaannya akan mengalami peningkatan dan juga sebaliknya. Hal ini menunjukkan sikap pertumbuhan pada perusahaan memberikan pengaruh yang positif bagi nilai perusahaan (Suastini et al., 2016)[4].

Beberapa penelitian sebelumnya yang berkaitan antar variabel sudah dilakukan oleh berbagai peneliti. Data dan informasi yang ditemukan juga bervariasi. Penelitian milik (Aniella et al., 2019)[5] menunjukan jika profitabilitas pada perusahaan memberikan pengaruh positif terhadap nilai pada suatu perusahaan . Penelitian lain menunjukkan hasil jika profitabilitas pada perusahaan bisa memberikan pengaruh yang negatif dan signifikan (Feby et al.,2018) [6]. Penelitian milik Wulan (2015)[7] menunjukan jika leverage mampu mempengaruhi nilai perusahaan secara positif. Penelitian yang lainnya yang memperlihatkan jika leverage tidak berpengaruh secara signifikan bagi perusahaan (Arastika dan Khairunnisa, 2020)[8]. Penelitian milik Suastini et al., (2016)[4] menunjukan hasil jika bertumbuhnya suatu perusahaan bisa memberikan pengaruh yang positif dan signifikan bagi nilai perusahaan itu sendiri. Penelitian lain milik Suwardika dan Mustanda (2017)[1] memperlihatkan jika pertumbuhan perusahaan mampu memberikan pengaruh yang negatif bagi nilai perusahaan .

Terdapat perbedaan hasil penelitian, sehingga penulis merasa tertarik untuk melakukan penelitian ini. Penelitian ini ingin membuktikan dan juga membandingkan, dan mengetahui apakah profitabilitas, leverage dan pertumbuhan perusahaan mempunyai pengaruh bagi nilai perusahaan di dua sektor perusahaan yang beda. Perbedaan penelitian ini dengan penelitian-penelitian sebelumnya terletak dalam tahun pelaksanaan penelitian serta perbedaan industri yang mana pada penelitian ini peneliti menggunakan perusahaan pada bidang pertambang batubara dan pertambangan minyak mentah dan gas alam. Sesuai dengan penjelasan permasalahan sebelumnya, sehingga peneliti merumuskan masalah yang akan dilakukan pembahasan pada kajian ini adalah membahas mengenai profitabilitas, leverage dan pertumbuhan perusahaan apakah mempunyai pengaruh yang positif bagi nilai perusahaan, profitabilitas apakah berpengaruh positif terhadap nilai perusahaan, mengenai leverage apakah memberikan pengaruh yang positif bagi nilai suatu perusahaan, mengenai pertumbuhan suatu perusahaan apakah memberikan pengaruh yang 
positif bagi nilai suatu perusahaan, bagaimana perbandingan pengaruh profitabilitas, leverage dan pertumbuhan perusahaan terhadap nilai perusahaan pada perusahaan sub sektor pertambangan batu bara dan sub sektor pertambangan minyak mentah dan gas alam yang sudah terdaftar di BEI periode 2015-2019.

\section{Kajian Literatur}

\section{Signalling Theory}

Menurut Fauziah (2017:11)[9] Teori sinyal ialah suatu teori utama pada aspek manajemen keuangan. Pada umumnya, sinyal dimaknai sebagai suatu tanda yang diberikan oleh perusahaan terhadap para investor. Sinyal ini bisa terbentuk pada model yang baik yang harus dilakukan pengamatan ataupun yang harus dilaksanakan pemahaman yang lebih lanjut agar bisa memahaminya. Teori ini dipakai untuk menjelaskan laporan keuangan yang pada dasarnya digunakan oleh sebuah perusahaan untuk memberi sinyal yang positif ataupun sinyal yang negatif untuk para pihak yang memakai.

Teori sinyal secara umum memfokuskan pada vitalnya data dan juga informasi yang dipublikasikan oleh suatu perusahaan untuk pihak lain yang akan berinvestasi. Data dan juga informasi ini merupakan unsur yang terpenting bagi pihak yang berinvestasi dan pelaku bisnis, dikarenakan informasi pada hakikatnya adalah memberikan keterangan, pencatatan maupun penggambaran, bisa berupa penggambaran keadaan masa lalu, masa sekarang ataupun keadaan berikutnya untuk kelangsungan hidup sebuah perusahaan serta bagaimana efek yang muncul (Ulum, 2015:29)[10].

\section{Nilai Perusahaan}

Nilai perusahaan ialah suatu ukuran yang memberikan gambaran terhadap keadaan harga perusahaan yang berada pada pasar. Gambaran ini bisa memberikan pengetahuan untuk pihak manajemen pada suatu industri mengenai situasi atau keadaan sebelum dilaksanakan serta bisa mengetahui dampak yang muncul di waktu nantinya (Fahmi, 2014:82)[11]. Nilai pada suatu perusahaan bisa dilakukan pengukuran dengan menggunakan nilai dari harga sahamnya di pasar, sesuai dengan terwujudnya harga tersebut pada pasar modal, yang termasuk suatu pemberian nilai yang berdasarkan refleksi oleh pihak lain mengenai kinerja yang ada pada suatu usaha atau industri. Harga saham di pasaran terbentuk karena adanya pertemuan antara jumlah permintaan dan juga jumlah penawaran. Pada umumnya transaksi yang terjadi adalah tindakan penjualan atau pembelian surat berharga yang ada pada pasar modal, yang dilakukan oleh emiten dan pihak yang akan membeli saham atau biasa dikenal dengan investor. Sehingga konsep nilai perusahaan merupakan harga saham suatu perusahaan yang berada pada pasar modal (Harmono, 2014:50)[12]. Nilai dari suatu perusahaan bisa dilihat dengan harga sahamnya yang dilakukan penerbitan pada pasar modal. Apabila harga pada saham ini semakin tinggi maka nilai perusahaan juga akan semakin tinggi yang berhubungan dengan tujuan yang ada pada perusahaan tersebut seperti mengoptimalkan kesejahteraan para pemegang saham (Utomo \& Christy, 2017)[13].

\section{Profitabilitas}

Hery (2016:192)[14] menjelaskan secara singkat profitabilitas ialah ukuran yang dipakai untuk melakukan pengukuran terhadap kompetensi suatu perusahaan dalam mendapatkan keuntungan dari kegiatan normal bisnis yang ada pada perusahaannya. Perusahaan merupakan suatu lembaga yang melakukan operasi dengan tujuan untuk mendapatkan profit dengan memperjualbelikan barang ataupun jasa kepada setiap konsumennya. keuntungan ini dipakai untuk melakukan pengukuran terhadap kompetensi 
perusahaan dalam mendapatkan keuntungan ataupun efektivitas yang berhubungan dengan pengelolaan manajemen pada sebuah perusahaan.

\section{Leverage}

Menurut Sujarweni (2017:61)[16] rasio leverage digunakan untuk melakukan pengukuran terhadap tingkat efektivitas perusahaan dalam memakai sumber daya yang di punya, sumber daya ini bisa berupa piutang dan juga modal ataupun aktiva. Rasio utang bagi model ialah rasio yang dipakai untuk melakukan pengukuran terhadap ukuran proporsi hutan bagi modal. Rasio ini mempunyai kegunaan untuk memahami ukuran perbandingan antara total keseluruhan dana yang dilakukan penyediaan oleh pihak kreditor dengan total keseluruhan modal yang dilakukan penyediaan oleh pihak yang memberikan dananya dengan menggunakan dana yang ada pada perusahaan. Rasio ini memberi isyarat dasar mengenai layaknya kredit serta risiko dari pihak debitur (Tarihoran, 2016)[17]

\section{Pertumbuhan Perusahaan}

Rasio pertumbuhan (growth) memperlihatkan mengenai persentase perkembangan suatu perusahaan dari masa ke masa. Data ataupun informasi mengenai tumbuhnya perusahaan sangat diperlukan oleh pihak yang akan berinvestasi dan pihak yang telah berinvestasi, lebih khususnya untuk yang merasa tertarik dalam menjalankan investasi pada saham tentunya. Investasi pada saham tentunya memiliki niat dalam jangka waktu yang lama serta memberi hasil yang lebih banyak dimasa yang akan datang (Harahap, 2015:309)[18]. Suatu usaha atau industri yang bisa melakukan pertumbuhan dengan cepat dapat mendapatkan hasil yang baik pada aspek pemantapan posisi pada masa persaingan, hal ini akan membuat penjualannya semakin mengalami peningkatan yang signifikan serta harga sahamnya pada pasar modal juga akan mengalami peningkatan, dengan adanya kejadian ini maka dengan tumbuhnya perusahaan secara cepat akan menyebabkan nilai perusahaan tersebut akan mengalami peningkatan (Suryandani, 2018)[19].

\section{Kerangka Pemikiran}

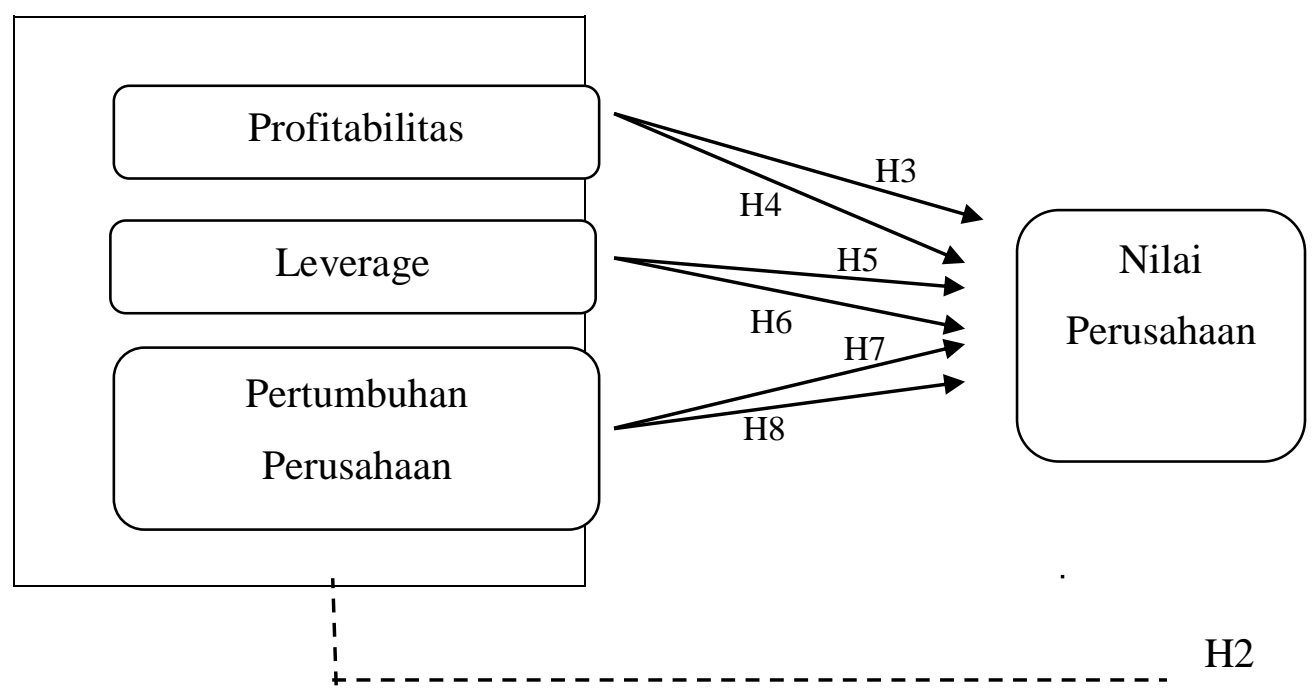

Gambar 2.1 Model Penelitian 
Keterangan:

- - : Variabel X secara simultan berpengaruh terhadap variable $\mathrm{Y}$

$\longrightarrow$ : Variabel $\mathrm{X}$ berpengaruh secara parsial terhadap variable $\mathrm{Y}$

\section{Metode Penelitian}

\section{Sampel}

Perusahaan pada bidang pertambang batubara dan juga perusahaan pertambang minyak mentah dan gas Alam periode 2015-2019, merupakan sampel yang dipakai dalam penelitian ini.

\section{Variabel Penelitian}

Variabel dependen pada kajian ini adalah nilai perusahaan yang diproksi dengan price book value, dihitung dengan pendapatan bersih sebelum dikenai pajak dibagi dengan jumlah keseluruhan aset. Variabel independen dalam kajian ini ialah profitabilitas yang diproksikan memakai Return on Asset (ROA), Leverage yang diproksikan dengan Debt to Equity Ratio (DER) dan Pertumbuhan perusahaan yang diproksikan dengan sales growth.

\section{Teknik Analisis Data}

Bentuk regresi berganda merupakan teknik analisis data yang dipakai pada kajian ini. Berikut ini ialah persamaan regresi yang dipakai pada kajian ini:

$$
\mathrm{Y}=\alpha 0+\beta 1 \mathrm{ROE}+\beta 2 \mathrm{DER}+\beta 3 \text { Growth }+
$$

Keterangan:

$\begin{array}{ll}\mathrm{Y} & : \text { Nilai Perusahaan } \\ \mathrm{A} & : \text { Konstanta } \\ \beta 1, \beta 2, \beta 3 & : \text { Koefisien Regresi } \\ \mathrm{X} 1 & : \text { Profitabilitas } \\ \mathrm{X} 2 & : \text { Leverage } \\ \mathrm{X} 3 & : \text { Growth } \\ \square & : \text { Error }\end{array}$

Tabel 1. Hasil Uji Statistik Deskriptif Pada Sub Sektor Pertambangan Batu Bara Tahun 2015-2019

DescriptiveStatistics

\begin{tabular}{|c|c|c|c|c|c|}
\hline & $\mathrm{N}$ & Min & Max & Mean & Std. Deviation \\
\hline PBV & 105 & -.37 & 17.06 & 1.8115 & 2.40457 \\
ROA & 105 & -64.39 & 45.56 & 6.2308 & 12.83081 \\
DER & 105 & -2.17 & 34.06 & 1.6850 & 3.78571 \\
SG & 105 & -.87 & 63.02 & 1.1070 & 7.05915 \\
Valid N (listwise) & 105 & & & & \\
\hline
\end{tabular}

Tabel 2. Hasil Uji Statistik Deskriptif Pada Sub Sektor Pertambangan Minyak Mentah dan Gas Alam Tahun 2015-2019

DescriptiveStatistics

\begin{tabular}{|c|c|c|c|c|c|}
\hline & $\mathrm{N}$ & Min & Max & Mean & Std. Deviation \\
\hline PBV & 50 & -20.56 & 13.53 & .4098 & 4.31633 \\
ROA & 50 & -153.83 & 8.62 & -9.0450 & 27.17812 \\
DER & 50 & -15.82 & 24.30 & 1.4844 & 5.86112 \\
SG & 50 & -1.00 & 7.31 & .2224 & 1.21470 \\
Valid N (listwise) & 50 & & & & \\
\hline
\end{tabular}


Tabel 3. Hasil Uji Kolmogorov-Smirnov Sub Sektor Pertambangan Batu Bara

One-Sample Kolmogorov-Smirnov Test

\begin{tabular}{|cc|c|}
\hline & & Unstandardized Residual \\
\hline $\mathrm{N}$ & Mean & 53 \\
Normal Parameters & & $0 \mathrm{E}-7$ \\
& Std. Deviation & .75412279 \\
& Absolute & .082 \\
MostExtremeDifferences & Positive & .082 \\
& Negative & -.062 \\
Kolmogorov-Smirnov Z & & .594 \\
Asymp. Sig. (2-tailed) & .872 \\
\hline
\end{tabular}

a. Test Distribution Is Normal.

b. Calculated From data.

Tabel 4. Hasil Uji Kolmogrov-Smirnov Sub Sektor Pertambangan Minyak Mentah dan Gas Alam

One-Sample Kolmogorov-Smirnov Test

\begin{tabular}{|cc|c|}
\hline & & Unstandardized Residual \\
\hline \multicolumn{2}{|c|}{$\mathrm{N}$} & Mean \\
Normal Parameters ${ }^{\mathrm{a}, \mathrm{b}}$ & Std. Deviation & $0 \mathrm{E}-7$ \\
& Absolute & .22833556 \\
& Positive & .183 \\
MostExtremeDifferences & Negative & .183 \\
& -.135 \\
Kolmogorov-Smirnov Z & .775 \\
Asymp. Sig. (2-tailed) & .584 \\
\hline
\end{tabular}

a. Test Distribution Is Normal.

b. Calculated From data.

Tabel 5. Hasil Uji Multikolinearitas Sub SektorPertambangan Batu Bara Coefficients $^{\mathrm{a}}$

\begin{tabular}{|c|c|c|c|c|c|c|c|}
\hline \multirow[t]{2}{*}{ Model } & \multicolumn{2}{|c|}{$\begin{array}{c}\text { Unstandardized } \\
\text { Coefficients }\end{array}$} & $\begin{array}{c}\text { Standardized } \\
\text { Coefficients }\end{array}$ & \multirow[t]{2}{*}{$\mathrm{T}$} & \multirow[t]{2}{*}{ Sig. } & \multicolumn{2}{|c|}{$\begin{array}{l}\text { Collinearity } \\
\text { Statistics }\end{array}$} \\
\hline & $\mathrm{B}$ & Std. Error & Beta & & & Tolerance & VIF \\
\hline (Constant) & -.223 & .186 & & -1.197 & .237 & & \\
\hline LN_ROA & .321 & .075 & .522 & 4.254 & .000 & .972 & 1.029 \\
\hline LN_DER & .161 & .131 & .150 & 1.223 & 227 & .972 & 1.029 \\
\hline LN_SG & .082 & .067 & .148 & 1.216 & .230 & .986 & 1.014 \\
\hline
\end{tabular}

Coefficients

\begin{tabular}{|c|c|c|c|c|c|c|c|c|}
\hline \multirow{2}{*}{\multicolumn{2}{|c|}{ Model }} & \multicolumn{2}{|c|}{$\begin{array}{c}\text { Unstandardized } \\
\text { Coefficients }\end{array}$} & \multirow{2}{*}{$\begin{array}{c}\begin{array}{c}\text { Standardized } \\
\text { Coefficients }\end{array} \\
\text { Beta }\end{array}$} & \multirow[t]{2}{*}{$\mathrm{T}$} & \multirow[t]{2}{*}{ Sig. } & \multicolumn{2}{|c|}{ Collinearity Statistics } \\
\hline & & B & $\begin{array}{l}\text { Std. } \\
\text { Error }\end{array}$ & & & & Tolerance & VIF \\
\hline \multirow{4}{*}{1} & (Constant) & .508 & .232 & & 2.187 & .046 & & \\
\hline & SQRT_ROA & .080 & .104 & .199 & .772 & .453 & 1.000 & 1.000 \\
\hline & SQRT_DER & .028 & .106 & .069 & .268 & .792 & .995 & 1.005 \\
\hline & SQRT SG & .061 & .097 & .163 & .633 & .537 & .995 & 1.005 \\
\hline
\end{tabular}


a. DependentVariable: SQRT_PBV

a. DependentVariable: LN_PBV

Tabel 6. Hasil Uji Multikolinearitas Sub Sektor Pertambangan Minyak Mentah dan Gas Alam

Tabel 7. Hasil Uji Autokorelasi Sub Sektor Pertambangan Batu Bara Model Summary

\begin{tabular}{|c|c|c|c|c|c|}
\hline Model & $\mathrm{R}$ & $\mathrm{R}$ Square & $\begin{array}{c}\text { Adjusted R } \\
\text { Square }\end{array}$ & $\begin{array}{c}\text { Std. } \\
\text { ErroroftheEstimate }\end{array}$ & Durbin-Watson \\
\hline 1 & $.532^{\mathrm{a}}$ & .284 & .240 & .77687 & 1.821 \\
\hline
\end{tabular}

a. Predictors: (Constant), LN_SG, LN_ROA, LN_DER

b. DependentVariable: LN_PBV

Tabel 8. Hasil Uji Autokorelasi Sub Sektor Pertambangan Minyak Mentah dan Gas Alam

\begin{tabular}{|c|c|c|c|c|c|}
\hline Model & $\mathrm{R}$ & R Square & $\begin{array}{c}\text { Adjusted R } \\
\text { Square }\end{array}$ & $\begin{array}{c}\text { Std. Error of the } \\
\text { Estimate }\end{array}$ & Durbin-Watson \\
\hline 1 & $.270^{\mathrm{a}}$ & .073 & -.126 & .25161 & 1.941 \\
\hline
\end{tabular}

a. Predictors: (Constant), SQRT_SG, SQRT_ROA, SQRT_DER

b. DependentVariable: SQRT_PBV

Tabel 9. Hasil Uji F pada Sub Sektor Pertambangan Batu Bara

\begin{tabular}{|cc|c|c|c|c|c|}
\hline \multirow{2}{*}{ Model } & $\begin{array}{c}\text { Sum of } \\
\text { Squares }\end{array}$ & Df & Mean Square & F & Sig. \\
\hline \multirow{3}{*}{1} & Regression & 11.704 & 3 & 3.901 & 6.464 & $.001^{\text {b }}$ \\
& Residual & 29.572 & 49 & .604 & & \\
& Total & 41.276 & 52 & & & \\
\hline
\end{tabular}

a. DependentVariable: LN_PBV

b. Predictors: (Constant), LN_SG, LN_ROA, LN_DER

Tabel 10. Hasil Uji F pada Sub Sektor Pertambangan Minyak Mentah dan Gas Alam ANOVA $^{\mathrm{a}}$

\begin{tabular}{|cc|c|c|c|c|c|}
\hline & Model & $\begin{array}{c}\text { Sum of } \\
\text { Squares }\end{array}$ & Df & Mean Square & F & Sig. \\
\hline \multirow{3}{*}{1} & Regression & .070 & 3 & .023 & .366 & $.779^{\mathrm{b}}$ \\
& Residual & .886 & 14 & .063 & & \\
& Total & .956 & 17 & & & \\
\hline
\end{tabular}

a. Dependent Variable: SQRT_PBV

b. Predictors: (Constant), SQRT_SG, SQRT_ROA, SQRT_DER 
Tabel 11. Hasil Uji t pada Perusahaan Sub Sektor Pertambangan Batu Bara Coefficients

\begin{tabular}{|c|c|c|c|c|c|c|c|}
\hline \multirow[t]{2}{*}{ Model } & \multicolumn{2}{|c|}{$\begin{array}{c}\text { Unstandardized } \\
\text { Coefficients }\end{array}$} & \multirow{2}{*}{$\begin{array}{c}\text { Standardized } \\
\text { Coefficients } \\
\text { Beta }\end{array}$} & \multirow[t]{2}{*}{$\mathrm{T}$} & \multirow[t]{2}{*}{ Sig. } & \multicolumn{2}{|c|}{$\begin{array}{c}\text { Collinearity } \\
\text { Statistics }\end{array}$} \\
\hline & $\mathrm{B}$ & Std. Error & & & & Tolerance & VIF \\
\hline (Constant) & -.223 & .186 & & $\overline{1} 197$ & .237 & & \\
\hline 1 LN_ROA & .321 & .075 & .522 & 4.254 & .000 & .972 & 1.029 \\
\hline LN_DER & .161 & .131 & .150 & 1.223 & .227 & .972 & 1.029 \\
\hline LN_SG & .082 & .067 & .148 & 1.216 & .230 & .986 & 1.014 \\
\hline
\end{tabular}

a. Dependent Variable: LN_PBV

Tabel 12. Hasil Uji t pada Perusahaan Sub Sektor Pertambangan Minyak Mentah dan Gas Alam

\begin{tabular}{|c|c|c|c|c|c|c|c|c|}
\hline \multicolumn{9}{|c|}{ Coefficients } \\
\hline \multirow{2}{*}{\multicolumn{2}{|c|}{ Model }} & \multicolumn{2}{|c|}{$\begin{array}{c}\text { Unstandardized } \\
\text { Coefficients } \\
\end{array}$} & $\begin{array}{c}\text { Standardized } \\
\text { Coefficients } \\
\end{array}$ & \multirow[t]{2}{*}{$\mathrm{T}$} & \multirow[t]{2}{*}{ Sig. } & \multicolumn{2}{|c|}{$\begin{array}{c}\text { Collinearity } \\
\text { Statistics }\end{array}$} \\
\hline & & $\mathrm{B}$ & $\begin{array}{l}\text { Std. } \\
\text { Error }\end{array}$ & Beta & & & Tolerance & VIF \\
\hline \multirow{4}{*}{1} & (Constant) & .508 & .232 & & 2.187 & .046 & & \\
\hline & SQRT_ROA & .080 & .104 & .199 & .772 & .453 & 1.000 & 1.000 \\
\hline & SQRT_DER & .028 & .106 & .069 & .268 & .792 & .995 & 1.005 \\
\hline & SQRT_SG & .061 & .097 & .163 & .633 & .537 & .995 & 1.005 \\
\hline
\end{tabular}

a. DependentVariable: SQRT_PBV

Tabel 13. Hasil Uji Koefisien Determinasi pada Perusahaan Sub SektorPertambangan Batu Baru

Model Summary

\begin{tabular}{|c|c|c|c|c|c|}
\hline Model & $\mathrm{R}$ & $\mathrm{R}$ Square & $\begin{array}{c}\text { Adjusted R } \\
\text { Square }\end{array}$ & $\begin{array}{c}\text { Std. Error of the } \\
\text { Estimate }\end{array}$ & Durbin-Watson \\
\hline 1 & $.532^{\mathrm{a}}$ & .284 & .240 & .77687 & 1.821 \\
\hline
\end{tabular}

a. Predictors: (Constant), LN_SG, LN_ROA, LN_DER

b. Dependent Variable: LN_PBV

Tabel 14. Hasil Uji Koefisien Determinasi pada Perusahaan Sub Sektor Pertambangan Minyak Mentah dan Gas Alam

Model Summary

\begin{tabular}{|c|c|c|c|c|c|}
\hline Model & $\mathrm{R}$ & $\mathrm{R}$ Square & $\begin{array}{c}\text { Adjusted R } \\
\text { Square }\end{array}$ & $\begin{array}{c}\text { Std. Error of the } \\
\text { Estimate }\end{array}$ & Durbin-Watson \\
\hline 1 & $.270^{\mathrm{a}}$ & .073 & -.126 & .25161 & 1.941 \\
\hline
\end{tabular}

a. Predictors: (Constant), SQRT_SG, SQRT_ROA, SQRT_DER

b. Dependent Variable: SQRT_PBV 


\section{Pembahasan Hasil Penelitian}

Perbandingan Uji Statistik Deskriptif pada Perusahaan Sub Sektor Pertambangan Batu Bara dan Sub Sektor Pertambangan Minyak Mentah dan Gas Alam

\begin{tabular}{|c|c|c|c|}
\hline Variabel & Deskriptif & \multicolumn{2}{|c|}{ Sektor } \\
\cline { 2 - 4 } & & Batu Bara & Minyak Mentah dan Gas Alam \\
\hline \multirow{4}{*}{ PBV } & Mean & 1,8115 & 0,4098 \\
\cline { 2 - 4 } & Maksimum & 17,06 & 13,53 \\
\cline { 2 - 4 } & Minimum & $-0,37$ & $-20,56$ \\
\hline \multirow{4}{*}{ ROA } & Mean & 6,2308 & $-9,0450$ \\
\cline { 2 - 4 } & Maksimum & 45,56 & 8,62 \\
\cline { 2 - 4 } & Minimum & $-64,39$ & $-153,83$ \\
\hline \multirow{4}{*}{ DER } & Mean & 1,6850 & 1,4844 \\
\cline { 2 - 4 } & Maksimum & 34,06 & 24,30 \\
\cline { 2 - 4 } & Minimum & $-2,17$ & $-15,82$ \\
\hline \multirow{2}{*}{ SG } & Mean & 1,1070 & 0,2224 \\
\cline { 2 - 4 } & Maksimum & 63,02 & 7,31 \\
\cline { 2 - 4 } & Minimum & $-0,87$ & $-1,00$ \\
\hline
\end{tabular}

Berdasarkan data pada tabel diatas diperoleh informasi variabel nilai perusahaan yang dihitung dengan menggunakan PBV dalam industri pertambangan batu bara memiliki nilai maksimum sejumlah 17,06 pada PT Atlas Resources Tbk periode 2018, dengan nilai ratarata sejumlah 1,8115 . sedangkan pada perusahaan sub sektor pertambangan minyak mentah dan gas alam memiliki nilai maksimum sebesar 13,53 pada perusahaan PT Apexindo Pratama duta Tbk periode 2015 dengan nilai rata-rata sejumlah 6,8426. Dari data yang di peroleh pada industri pertambangan batu bara dan pertambangan minyak mentah dan gas alam nilai rata-rata industri pada sub sektor pertambangan batu bara lebih besar apabila dilakukan perbandingan dengan nilai rata-rata industry minyak mentah dan gas alam.

Profitabilitas yang diproksikan dengan ROA dalam industri pertambangan batu bara memiliki nilai maksimum sejumlah 45,56 pada PT Bayan Resources Tbk periode 2018 dengan nilai rata-rata sebesar 6,2308. sedangkan pada perusahan pertambangan minyak mentah dan gas alam memiliki nilai maksimum sebesar 8,62 pada perusahaan PT Elnusa Tbk periode 2015 dengan nilai rata-rata sejumlah -9,0450. Dari data yang diperoleh pada perusahaan tambang batu bara dan perusahaan pertambangan minyak mentah dan gas alam nilai rata-rata industry ROA dalam industri pertambangan batu bara lebih besar dibandingkan dengan nilai rata-rata industri ROA dalam industri pertambangan minyak mentah dan gas alam.

Leverage yang diproksikan dengan DER dalam industri pertambangan batubara memiliki nilai maksimum yang berjumlah 34,06 pada PT Atlas Resources Tbk periode 2018 dengan nilai rata-rata sebesar 6,850. sedangkan pada perusahaan sub sektor pertambangan minyak mentah dan gas alam memiliki nilai maksimum sebesar 24,30 pada PT Apexindo Pratama Duta Tbk periode 2016 dengan nilai rata-rata sejumlah 1,4844. Dari data yang diperoleh pada perusahaan pertambangan batu bara dan perusahaan pertambangan minyak mentah dan gas alam dengan rata-rata nilai industry DER pada pada industri pertambangan batubara lebih banyak dibanding dengan nilai rata-rata pertambangan minyak mentah dan gas alam.

Pertumbuhan perusahaan yang diproksikan dengan Sales Growth pada perusahaan sub sektor pertambangan batu bara memiliki memiliki nilai maksimum sebesar 63,02 seperti yang terdapat pada PT Bumi Resources Tbk periode 2018 dengan nilai rata-rata sejumlah 
1,1070. Sedangkan pada perusahaan sub sektor pertambangan minyak mentah dan gas alam memiliki nilai maksimum sebesar 7,31 pada PT Astrindo Nusantara Infrastructure Tbk tahun 2018 dengan nilai rata-rata sejumlah 0,2224. Dari data yang diperoleh pada perusahaan sub sektor pertambangan batu bara dan industri pertambangan minyak mentah dan gas alam nilai rata-rata industry sales growth pada industri pertambangan batu bara lebih besar dibandingkan dengan nilai rata-rata industry variabel Sales Growth pada pertambangan minyak mentah dan gas alam

Dari hasil perhitungan konstanta yang dihasilkan kecil hal ini berpengaruh pada nilai Adjusted R Square pada industri pertambangan batu bara yang dihasilkan senilai 0,240 ini berarti hanya $24 \%$ variabel dependen price book value dipengaruhi variabel bebasnya yaitu profitabilitas, leverage dan pertumbuhan perusahaan. Sehingga hal ini yang berpengaruh hanya nilai ROA. Sedangkan sisanya $76 \%$ dijelaskan oleh aspek lainnya yang tidak terdapat di variabel yang dipakai pada kajian ini. Konstanta pada industri pertambang minyak mentah dan gas alam kecil hal ini berpengaruh pada adjusted $\mathrm{R}$ Square yang diperoleh senilai $-0,126$ hal ini memberikan arti jika variabel bebasnya tidak memberikan pengaruh bagi variabel terikatnya. Jadi bukan variabel profitabilitas, leverage dan pertumbuhan perusahaan yang dapat mempengaruhi nilai perusahaan pada perusahaan pertambangan minyak mentah dan gas alam.

\section{H1 : Profitabilitas, Leverage dan Pertumbuhan Perusahaan Berpengaruh secara simultan terhadap nilai perusahaan pada perusahaan sub-sektor pertambangan batu bara yang terdaftar di BEI pada tahun 2015-2019.}

Hasil kajian dengan uji $\mathrm{F}$ memperlihatkan jika variabel profitabilitas, leverage dan pertumbuhan perusahaan memberikan pengaruh secara persamaan bagi nilai perusahaan. Hal ini dibuktikan dengan adanya nilai signifikansi kurang dari 0,05 atau sebesar 0,001.

Hasil ini didukung oleh kajian yang dilaksanakan oleh Suwardika dan Mustanda (2017) yang menjelaskan jika profitabilitas, leverage dan pertumbuhan perusahaan memberikan pengaruh yang signifikan bagi nilai perusahaan.

\section{H2 : Profitabilitas, Leverage dan Pertumbuhan Perusahaan Berpengaruh secara simultan terhadap nilai perusahaan pada perusahaan subsektor pertambangan minyak mentah dan gas alam yang terdaftar di BEI pada tahun 2015-2019.}

Hasil kajian dengan uji $\mathrm{F}$ Memperlihatkan jika variabel profitabilitas, leverage dan pertumbuhan perusahaan tidak memberikan pengaruh secara bersamaan bagi nilai perusahaan. Hal ini dibuktikan dengan adanya nilai signifikansi lebih dari 0,05 atau sebesar 0,181 .

Adanya dukungan dari penelitian terdahulu yang dilakukan oleh Catur dan Riani (2017), Novari dan Lestari (2016) bahwa profitabilitas, leverage dan pertumbuhan perusahaan tidak memberikan pengaruh yang besar bagi nilai perusahaan.

\section{H3 : Profitabilitas berpengaruh positif terhadap nilai perusahaan pada perusahaan sub-sektor pertambangan batubara yang terdaftar di BEI pada tahun 2015- 2019.}

Hasil kajian dengan uji T Memperlihatkan jika variabel profitabilitas memiliki pengaruh positif bagi nilai perusahaan. Hal ini dibuktikan dengan adanya nilai t senilai 4,254 serta adanya nilai signifikansi kurang dari 0,05 atau sebesar 0,000.

Penelitian ini menghasilkan data atau informasi yang mempunyai kesamaan dengan penelitian yang dilaksanakan oleh Lidya dkk (2018), Novari dan Lestari (2016) jika profitabilitas memberikan bisa mempengaruhi nilai perusahaan secara signifikan. 
H4 : Profitabilitas berpengaruh Positif terhadap nilai perusahaan pada perusahaan subsektor pertambangan minyak mentah dan gas alam yang terdaftar di BEI pada tahun 2015-2019.

Hasil penelitian dengan uji $\mathrm{T}$ Memperlihatkan variabel profitabilitas tidak mempunyai pengaruh bagi nilai perusahaan. Hal ini juga dibuktikan dari adanya nilai t sebesar 0,772 dan nilai signifikansi lebih dari 0,05 atau senilai 0,453.

Penelitian ini menghasilkan data atau informasi yang sama dengan penelitian yang dilaksanakan oleh Sambora dkk (2015) jika profitabilitas tidak memberikan pengaruh bagi nilai perusahaan.

H5 : Leverage berpengaruh positif terhadap nilai perusahaan pada perusahaan subsektor pertambangan batubara yang terdaftar di BEI pada tahun 2015-2019.

Hasil penelitian dengan uji $\mathrm{T}$ Memperlihatkan jika variabel leverage tidak mempunyai pengaruh bagi nilai perusahaan. Hal ini dibuktikan dengan adanya nilai t terbukti dari nilai t sebesar 1,223 dan nilai signifikansi lebih dari 0,05 atau senilai 0,227.

Penelitian ini menghasilkan data atau informasi yang sama dengan kajian yang diteliti oleh Putu dan Yadnya (2020) memperlihatkan bahwa leverage memberikan pengaruh yang baik dan tidak signifikan bagi nilai perusahaan.

H6 : Leverage memberikan pengaruh yang positif terhadap nilai perusahaan pada perusahaan subsektor pertambangan minyak mentah dan gas alam yang terdaftar di BEI pada tahun 2015-2019.

Hasil kajian dengan uji $\mathrm{T}$ Memperlihatkan jika variabel leverage tidak mempunyai pengaruh pada nilai perusahaan. Hal ini dibuktikan dengan adanya nilai t sebesar 0,268 dan nilai signifikansi lebih dari 0,05 atau senilai 0,792 .

Penelitian ini menghasilkan data atau informasi yang memiliki kesamaan dengan kajian yang diteliti oleh Putu dan Yadnya (2020) menunjukkan bahwa leverage memberikan pengaruh yang baik dan tidak signifikan terhadap nilai perusahaan.

H7 : Pertumbuhan Perusahaan Memberikan pengaruh yang positif terhadap nilai perusahaan pada perusahaan sub-sektor pertambangan batu bara yang sudah didaftarkan kan di BEI pada tahun 2015-2019.

Hasil penelitian dengan pengujian $\mathrm{t}$ memperlihatkan jika variabel pertumbuhan perusahaan tidak memberikan pengaruh bagi nilai perusahaan. Hasil ini dibuktikan dengan adanya nilai t sejumlah 1,216 dan nilai signifikan nya lebih dari 0,05 atau senilai 0,230.

Terdapat kesamaan antara hasil kajian ini dengan kajian yang dilaksanakan oleh Atika Suryandani (2018) jika pertumbuhan perusahaan memberikan pengaruh yang baik bagi nilai perusahaan.

H8 :Pertumbuhan Perusahaan Memberikan pengaruh yang positif bagi nilai perusahaan pada perusahaan yang bergerak di bidang pertambangan minyak mentah dan gas alam yang yang sudah didaftarkan pada BEI pada tahun 20152019.

Hasil penelitian dengan pengujian memperlihatkan jika variabel pertumbuhan perusahaan tidak mempunyai pengaruh pada nilai perusahaan. Hal ini dibuktikan adanya nilai $\mathrm{t}$ sejumlah 0,633 dan nilai signifikannya nya lebih besar dari 0,05 atau senilai 0,537.

Terdapat kesamaan di antara hasil kajian ini dengan kajian yang dilaksanakan oleh Atika Suryandani (2018) jika pertumbuhan perusahaan mampu memberi pengaruh yang baik bagi nilai perusahaan. 


\section{Kesimpulan}

1. Hasil pengujian hipotesis profitabilitas, leverage dan pertumbuhan perusahaan secara bersamaan memberikan pengaruh bagi nilai perusahaan pada pertambangan batubara. hal ini dibuktikan dengan uji simultan (Uji F) dimana terdapat pengaruh signifikan, artinya $\mathrm{H}_{1}$ diterima.

2. Hasil pengujian hipotesis profitabilitas, leverage dan pertumbuhan perusahaan secara persamaan tidak memberikan pengaruh pada nilai perusahaan pada industri pertambangan minyak mentah dan gas alam hal ini dibuktikan dengan uji simultan (Uji F) dimana terdapat pengaruh signifikan, artinya $\mathrm{H}_{2}$ ditolak

3. Hasil pengujian hipotesis profitabilitas yang diproksikan oleh ROA membuktikan jika variabel profitabilitas memberikan pengaruh bagi nilai perusahaan dalam industri pertambang batubara. Hal ini dibuktikan dengan uji parsial (uji t) dimana terdapat pengaruh profitabilitas terhadap nilai perusahaan artinya $\mathrm{H} 3$ diterima.

4. Dari hasil pengujian profitabilitas yang diproksikan oleh ROA membuktikan bahwa variabel profitabilitas tidak berpengaruh bagi nilai perusahaan industri pertambang minyak mentah dan gas alam hal ini dibuktikan dengan uji parsial (uji t) dimana profitabilitas tidak memberikan pengaruh bagi nilai perusahaan artinya $\mathrm{H} 4$ ditolak

5. Hasil pengujian hipotesis leverage yang diproksikan dengan DER membuktikan jika variabel leverage tidak memberikan pengaruh bagi nilai perusahaan pada industri perambang batu bara hal ini dibuktikan dengan uji parsial (uji t) dimana leverage tidak memberikan pengaruh bagi nilai perusahaan artinya $\mathrm{H}_{5}$ ditolak.

6. Hasil pengujian hipotesis leverage yang diproksikan dengan DER membuktikan jika variabel leverage tidak memberikan pengaruh pada nilai perusahaan dalam industri pertambang minyak mentah dan gas alam hal ini dibuktikan dengan uji parsial (uji t) dimana leverage tidak memberikan pengaruh bagi nilai perusahaan artinya $\mathrm{H}_{6}$ ditolak.

7. Dari hasil uji hipotesis pertumbuhan perusahaan yang diproksikan dengan sales growth mendapatkan bukti jika variabel pertumbuhan perusahaan tidak memberikan pengaruh bagi nilai perusahaan pada perusahaan yang bergerak di bidang pertambangan batubara, hal ini dibuktikan dengan uji parsial (uji t) dimana leverage tidak memberikan pengaruh bagi nilai perusahaan sehingga hal ini berarti $\mathrm{H}_{7}$ ditolak.

8. Hasil pengujian hipotesis pertumbuhan perusahaan yang dilakukan dengan sales growth membuktikan bahwa variabel pertumbuhan perusahaan tidak berpengaruh bagi nilai perusahaan dalam industri tambang minyak mentah serta gas alam. Hal ini dibuktikan dengan uji parsial (uji t) dimana tidak adanya pengaruh pertumbuhan bagi nilai perusahaan sehingga hal ini berarti $\mathrm{H}_{8}$ ditolak. 


\section{Daftar Pustaka}

[1] Suardika, I. and Mustanda, I. (2017) Pengaruh Leverage, Ukuran Perusahaan, Pertumbuhan Perusahaan, Dan Profitabilitas Terhadap Nilai Perusahaan Pada Perusahaan Properti. None, 6, 254488.

[2] Ecodemica, J., April, V.N., Hertina, D., Bayu, M., Hidayat, H. and Mustika, D. (2019) Ukuran Perusahaan, Kebijakan Hutang Dan Profitabilitas. 3.

[3] Wahyudi, E. (2016) Kolaborasi Riset Dosen Dan Mahasiswa. CoreAcUk,.

[4] Suastini, N.M., Ida, B.A.P. and Henny, R. (2016) Pertumbuhan Perusahaan Terhadap Nilai Perusahaan Pada Perusahaan Manufaktur Di Bursa Efek Indonesia (Struktur Modal sebagai Variabel Moderasi). Jurnal Ekonomi Dan Bisnis Universitas Udayana, 5, 143-72.

[5] Nurminda, A., Wisnuwardhana, D. and Nurbaiti, A. (2017) The Influence Of Profitability, Leverage, and Size Toward Firm Value ( Study Of Manufacture Companies Goods And Foods Sub Sector Listed in Indonesia Stock Exchange 20122015 ). E-Proceeding of Management, 4, 542-9.

[6] Suryana, F.N. and Rahayu, S. (2018) Pengaruh Leverage, Profitabilitas, dan Ukuran Perusahaan Terhadap Nilai Perusahaan (Studi Empiris pada Perusahaan Industri Barang Konsumsi Sub Sektor Farmasi yang Terdaftar di Bursa Efek Indonesia Tahun 2012-2016). E-Proceeding of Management, 5, 2262-9.

[7] Sholichah, W.A. (2015) Pengaruh Struktur Kepemilikan, Ukuran Perusahaan Dan Leverage Terhadap Nilai Perusahaan. Jurnal ILmu \& Riset Akuntansi, 4, 1-17.

[8] Arastika, I.P. and Khairunnisa. (2020) Pengaruh leverage , profitabilitas dan pertumbuhan perusahaan terhadap nilai perusahaan. Jurnal Wawasan Dan Riset Akuntansi, 7, 125-33.

[9] Fauziah, F. (2017) Kesehatan Bank, Kebijakan Dividen dan Nilai Perusahaan: Teori dan Kajian Empiris. 1st ed. RV Pustaka Horizon, Samarinda.

[10] Ulum, I. (2015) Intellectual capital model pengukuran framework pengungkapan dan kinerja organisasi. Graha Ilmu, Yogyakarta.

[11] Fahmi, I. (2014) Manajemen Keuangan Perusahaan dan Pasar Modal. Mitra wacana media.

[12] Harmono. (2014) Manajemen Keuangan : Berbasis Balanced Scorecard. PT Bumi Aksara, Jakarta.

[13] Utomo, N.A. and Christy, N.N.A. (2017) Pengaruh Struktur Modal, Profitabilitas, Ukuran Perusahaan terhadap Nilai Perusahaan pada Perusahaan LQ45 di Bursa Efek Indonesia. Bingkai Manajemen, 398-415.

[14] Hery. (2016) Analisis Laporan Keuangan. cetakan pe. Adi Pramono, editor. PT Grasindo, Jakarta.

[15] V.Wiratna Sujarweni. (2017) Analisis Laporan Keuangan. Pustaka Baru Press, Yogyakarta.

[16] V.Wiratna Sujarweni. (2017) Analisis Laporan Keuangan. Pustaka Baru Press, Yogyakarta.

[17] Tarihoran, A. (2016) Pengaruh Penghindaran Pajak dan Leverage Terhadap Nilai Perusahaan dengan Transparansi Perusahaan Sebagai Variabel Moderasi. Jurnal Wira Ekonomi Mikroskil, 6, 149-64.

[18] Harahap, S. (2015) Teori Akuntansi. cetakan 15. PT Rajagrafindo Persada.

[19] Suryandani, A. (2018) Pengaruh Pertumbuhan Perusahaan, Ukuran Perusahaan, Dan Keputusan Investasi Terhadap Nilai Perusahaan Pada Perusahaan Sektor Property Dan Real Estate Di Bei. BMAJ: Business Management Analysis Journal, 1, 49-59. 